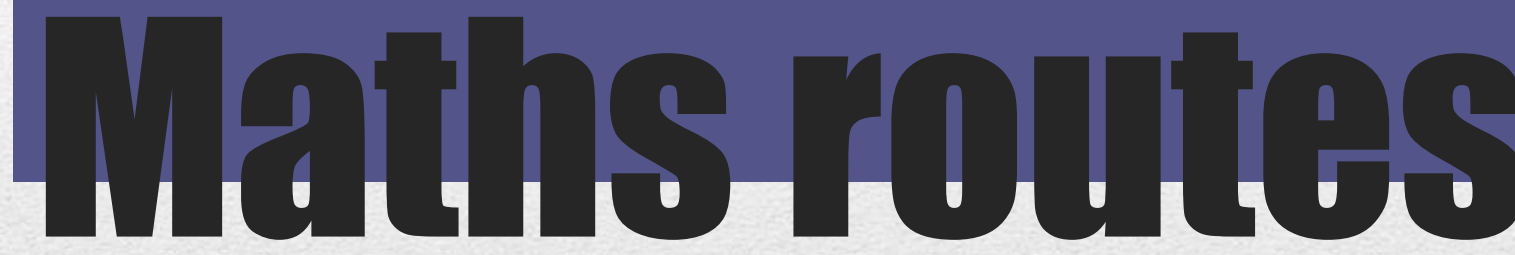

\title{
around Europe.
}

Úbeda Julio 2019

\section{Presentado en eXIDO19 (2019) (c) (1) (3)}




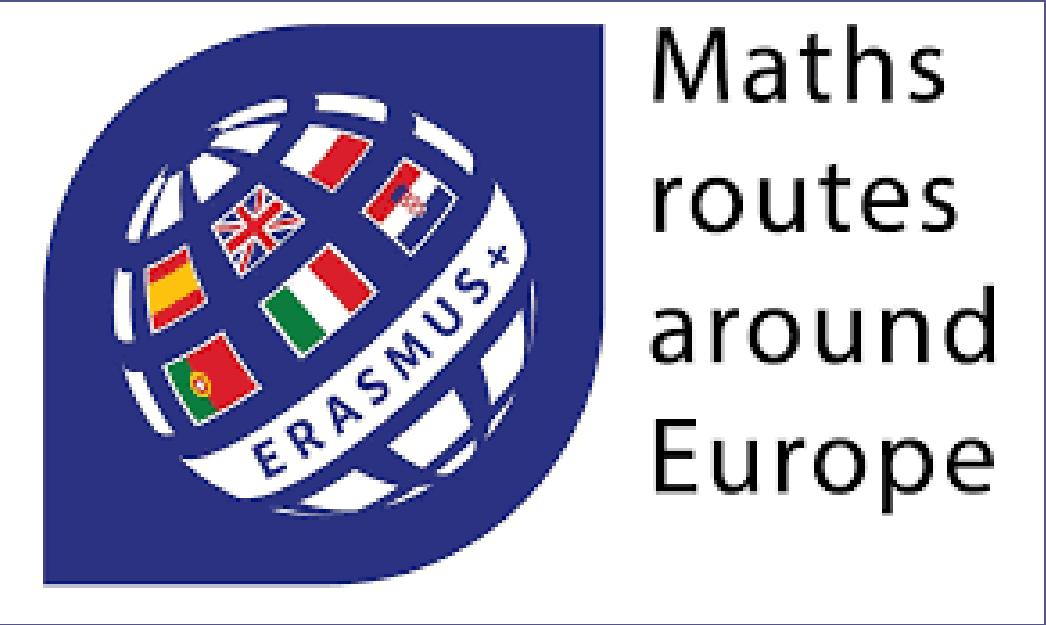

Proyecto Erasmus+ coordinado por el IES Alfonso XI 2018-2020

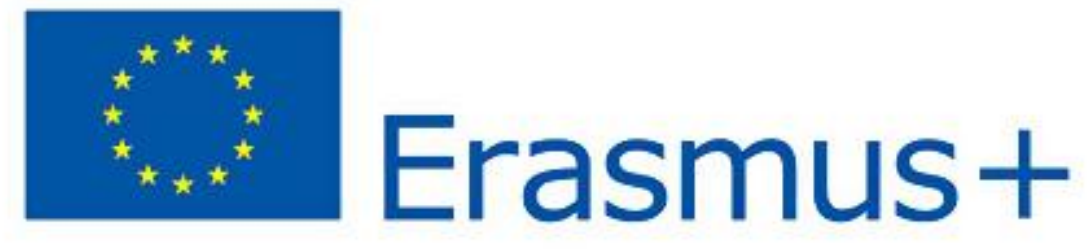

https://erasmusplusmaths.wixsite.com/ erasmusplusmaths 


\section{Uno}

EL POR QUÉ DEL PROYEQTO 

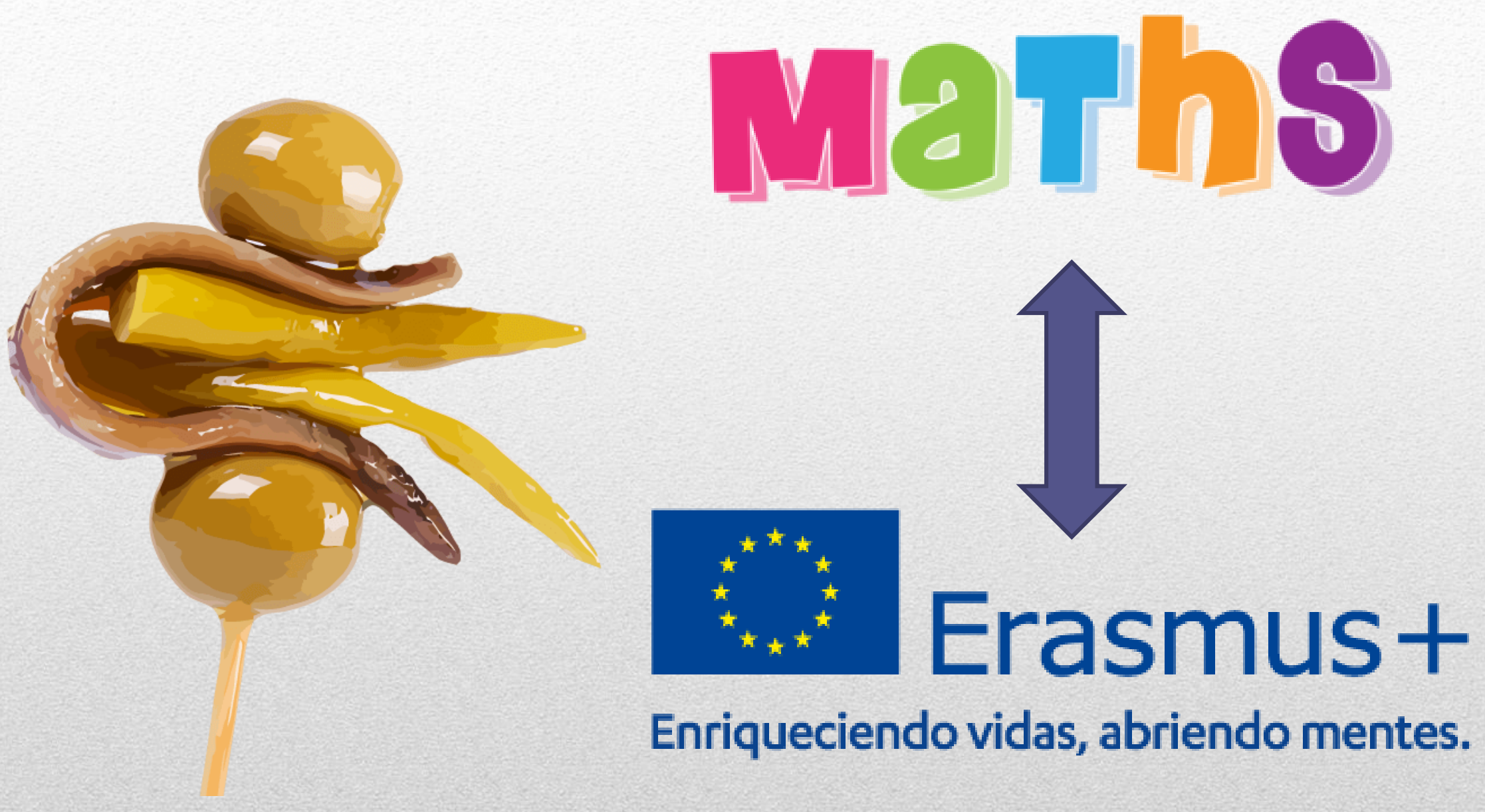

Enriqueciendo vidas, abriendo mentes. 


\section{8 AÑO EUROPEO DEL PATRIMONIO CULTURAL \#EuropeForCulture}

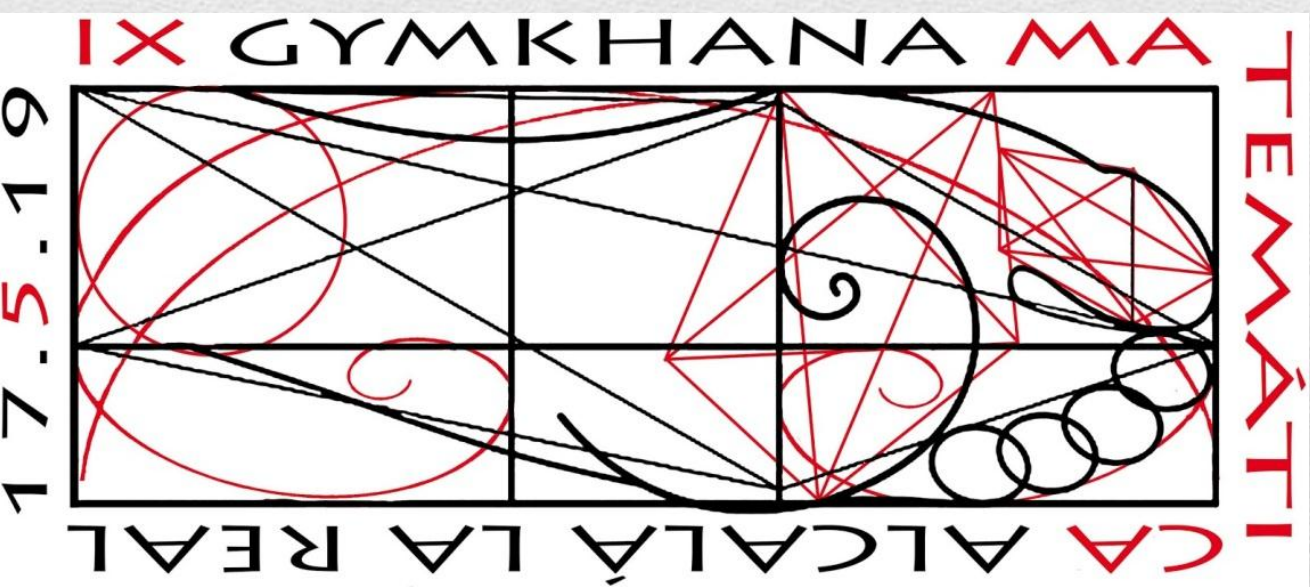

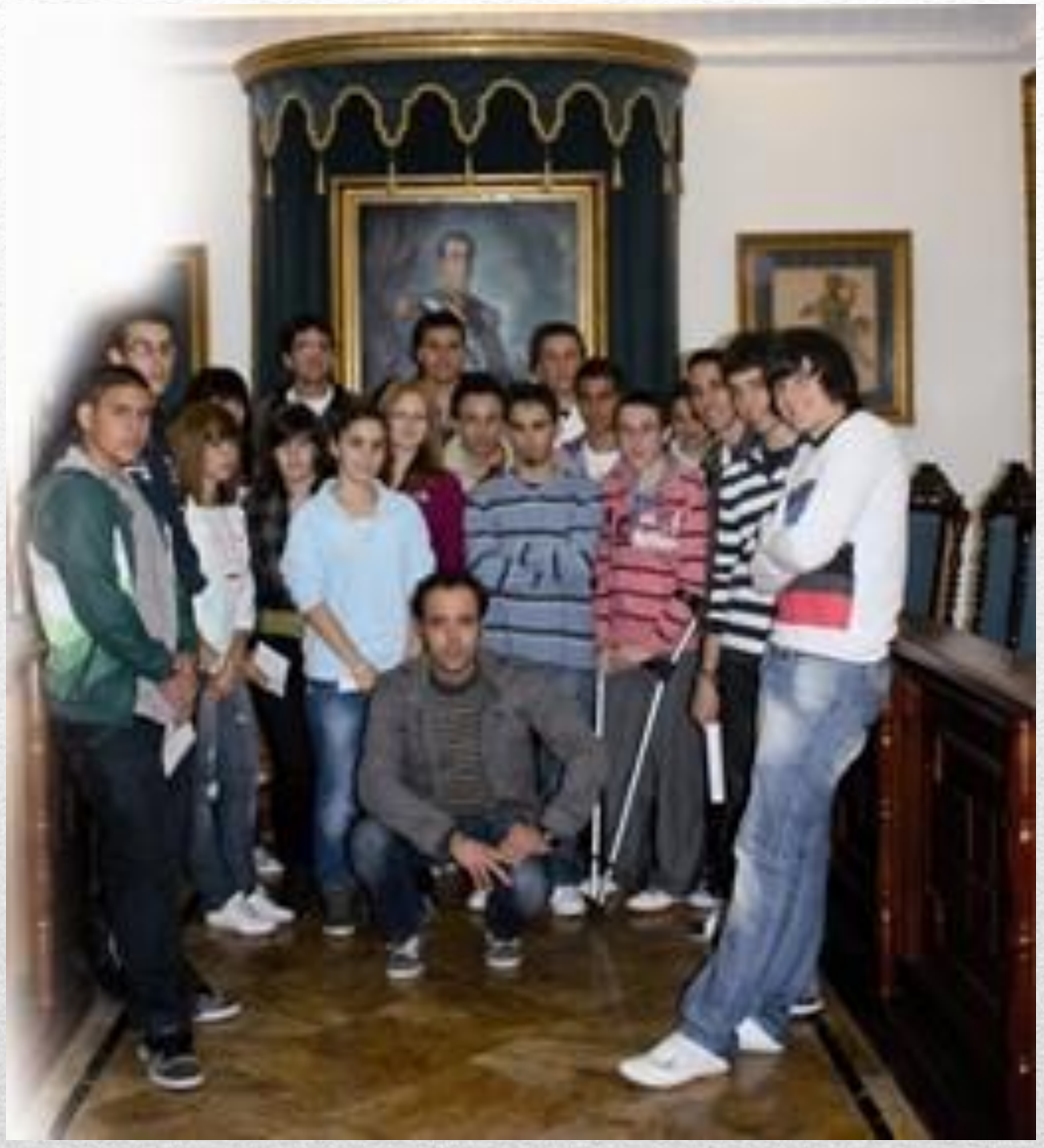

http://provintealfonso11.wix.com/ paseosmatematicos

Los paseos matemáticos 2011 y las Gymkhanas como origen del proyecto 


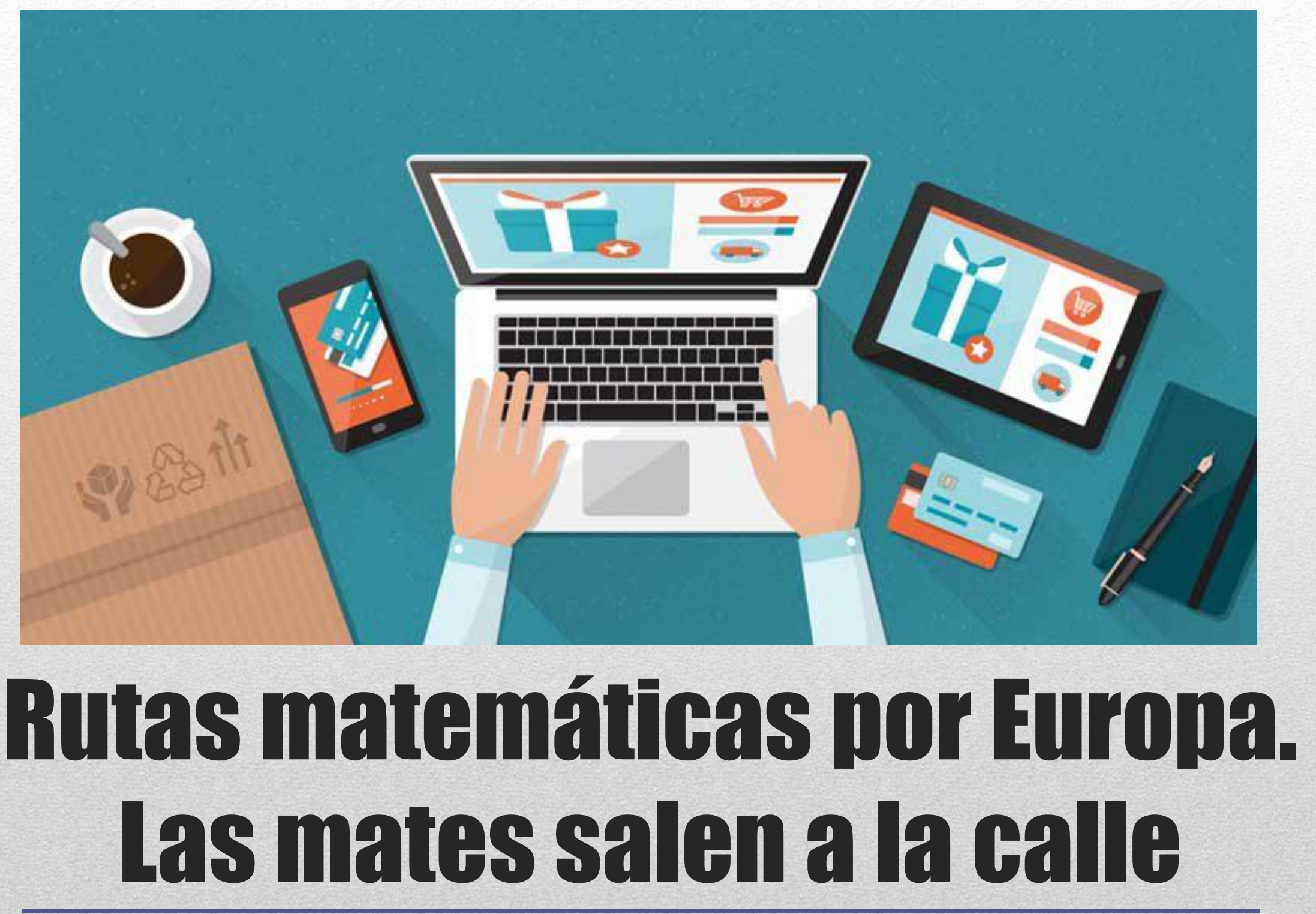




\section{Dos}

QUIENES FORMAN EL PROYECTO 
- IES Alfonso XI. Spain. Alcalá la Real.

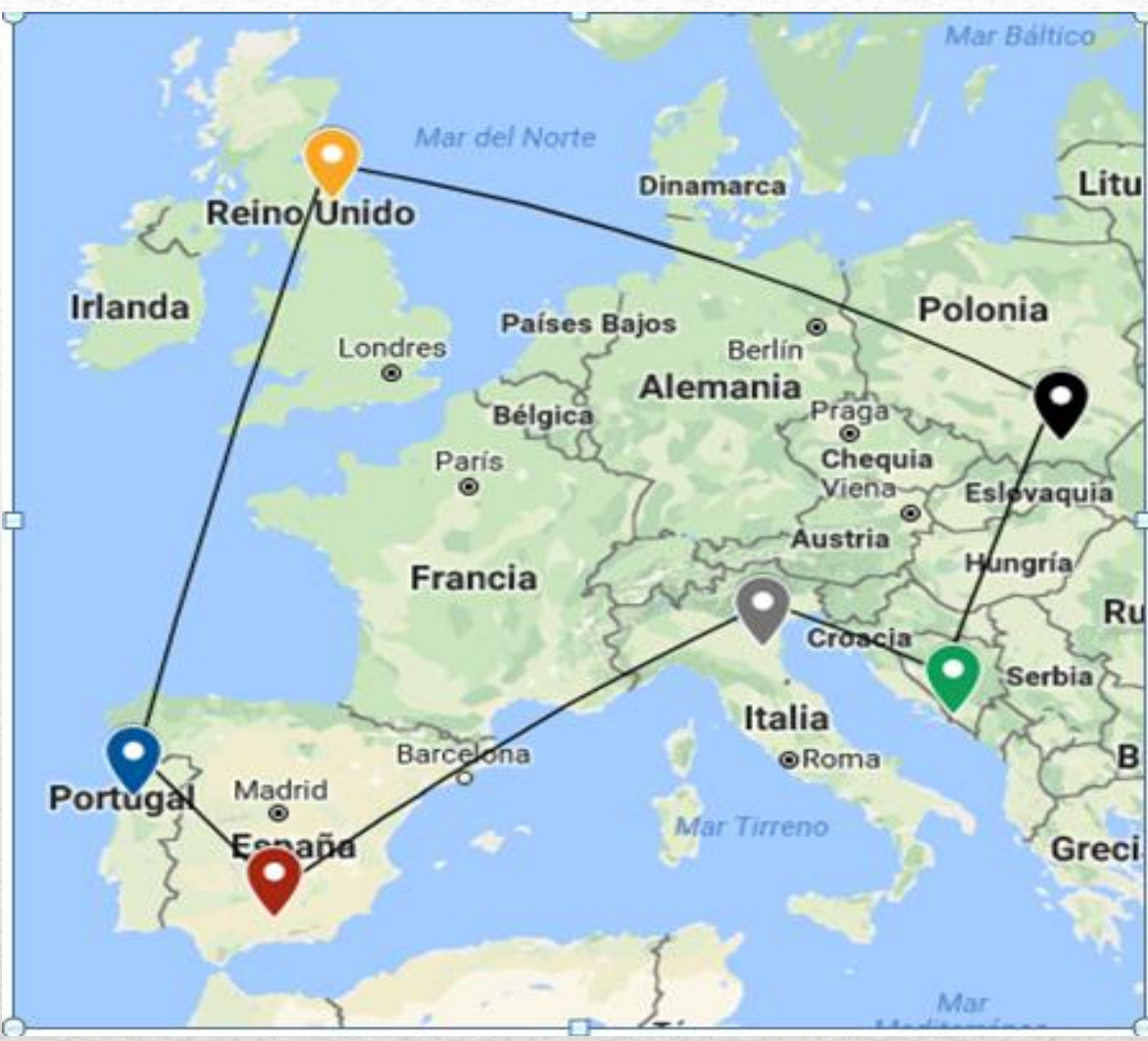

- Agrupamento de Escolas de Ferreira de Castro. Portugal. Oliveira de Azeméis.

- Gimnazija Metkovic. Croatia. Metkovic.

- The Northumberland Church of England Academy United Kingdom. Ashington

- Liceo Roiti. Italy. Ferrara.

- Liceum Ogolnoksztalcace im. Mikolaja Kopernika. Poland. Tuchow Profesorado y alumnado de 6 países. 


\section{T \\ Tres}

QUÉ ESTAMOS HACIENDO 

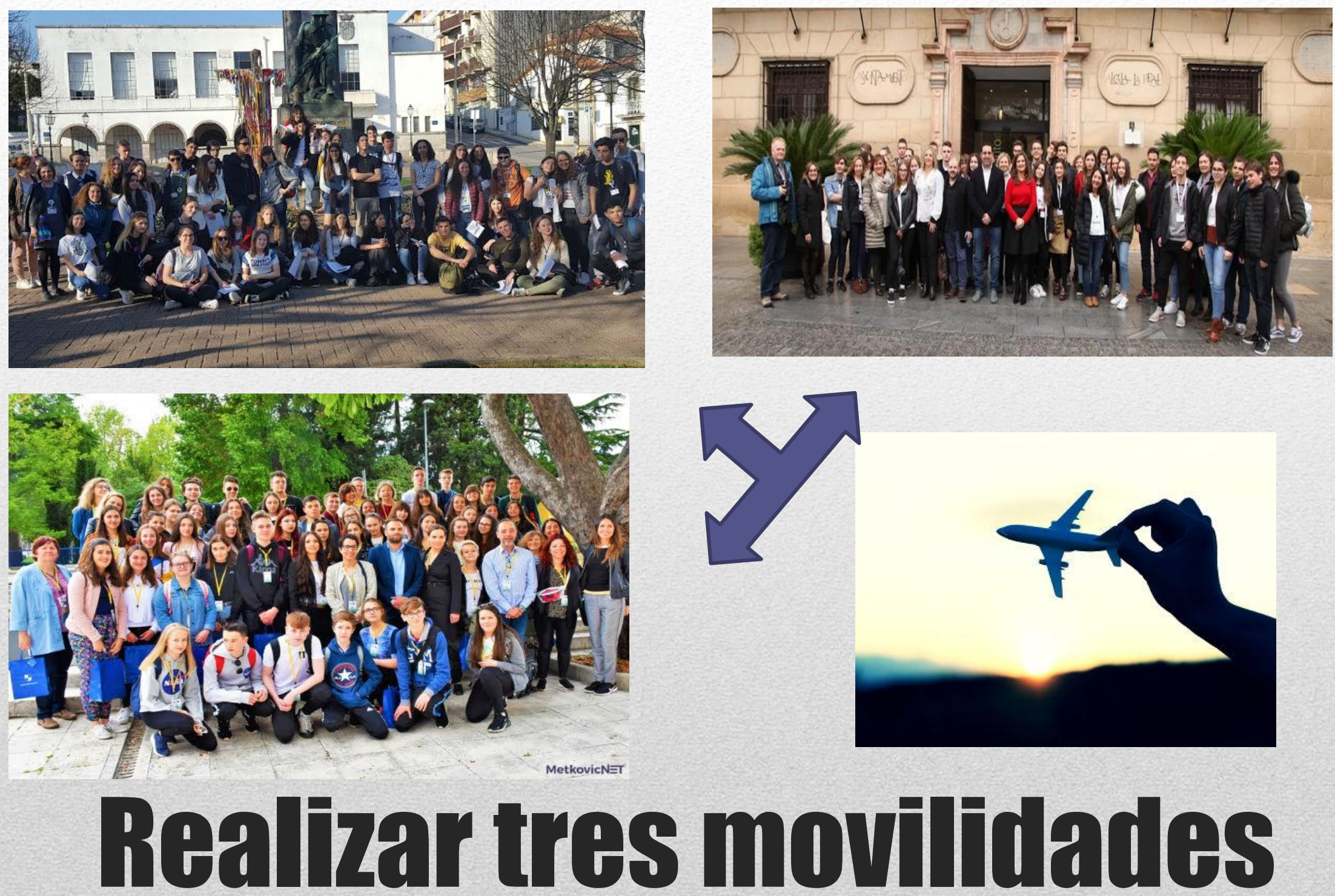
A28: $\quad 040$

E1 $\quad A \quad A-92$ Or to

\section{A41}

\section{A32}

\section{E1}

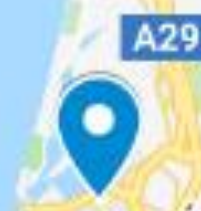

Vagos Águeda

o

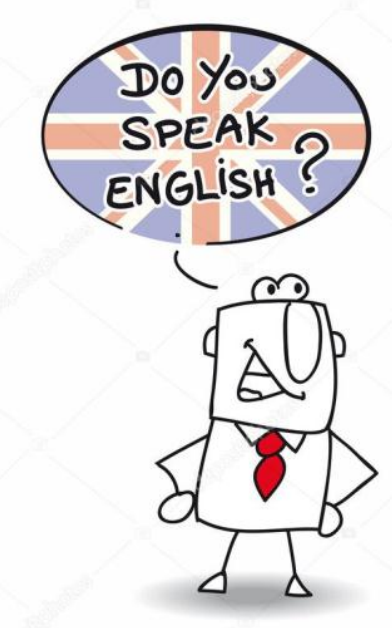

Gra...ua

Armilla
Sierı
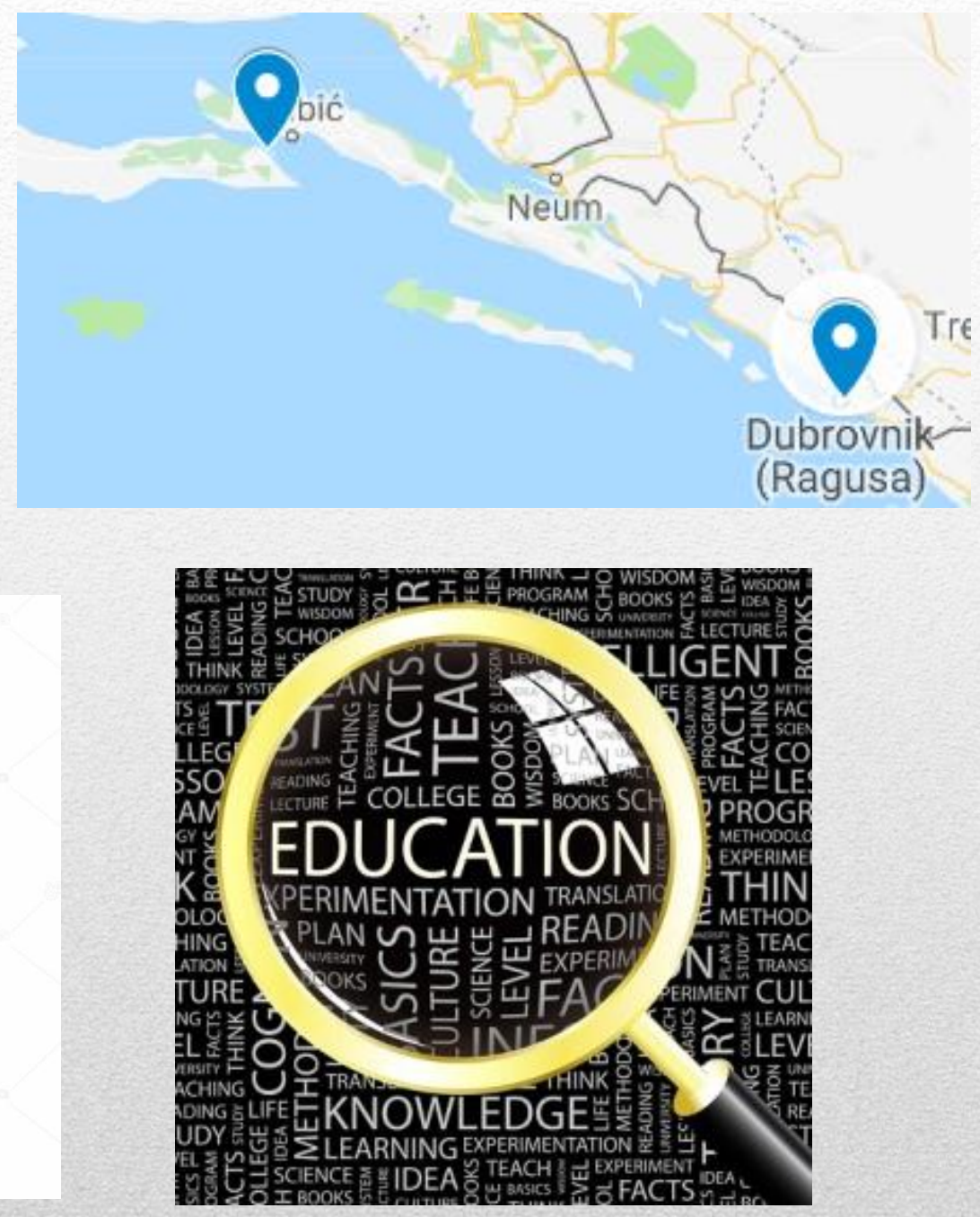

\section{Visitando lugares fantásticos y..}



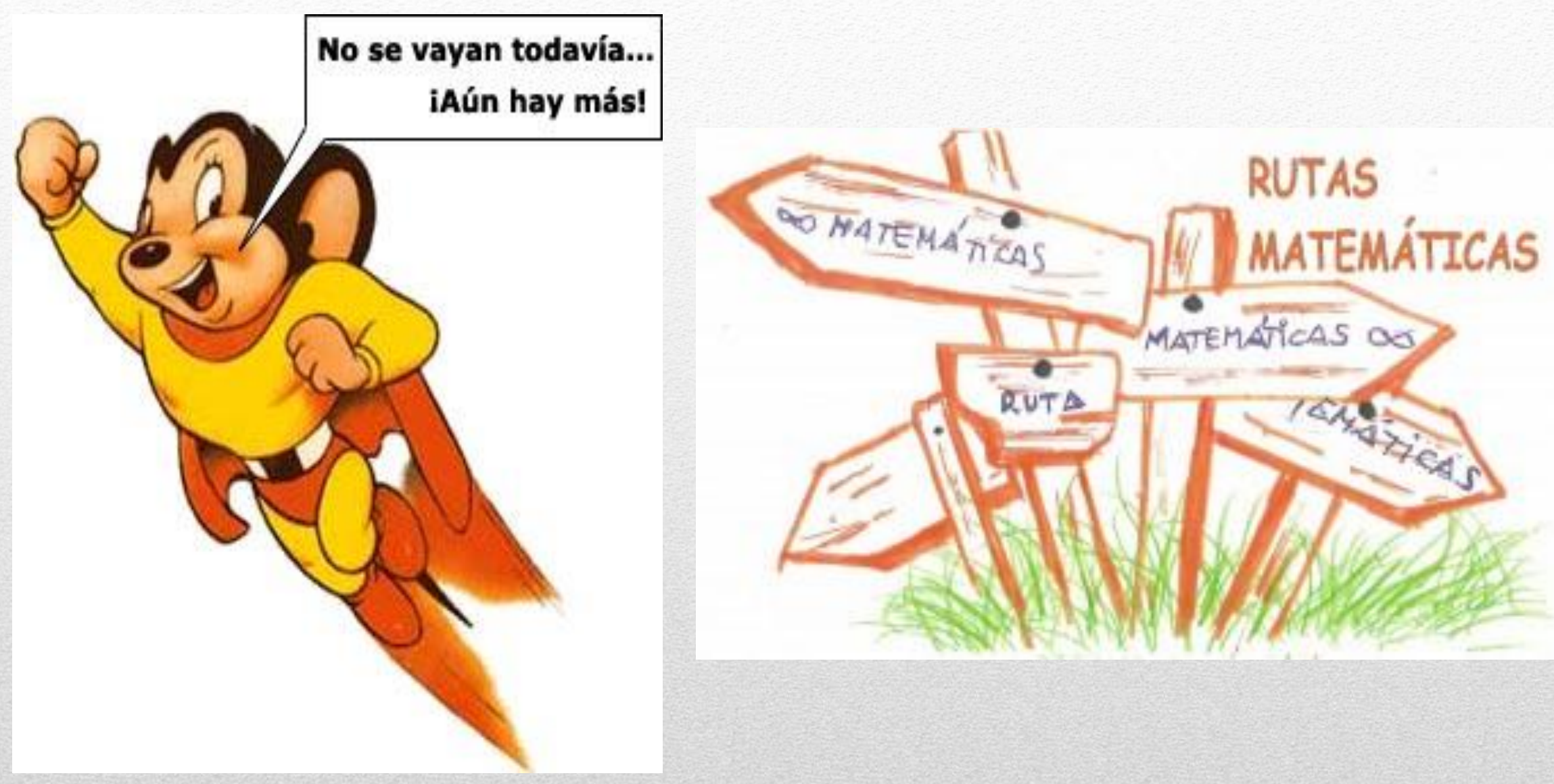

Objetivo principal del provecto 

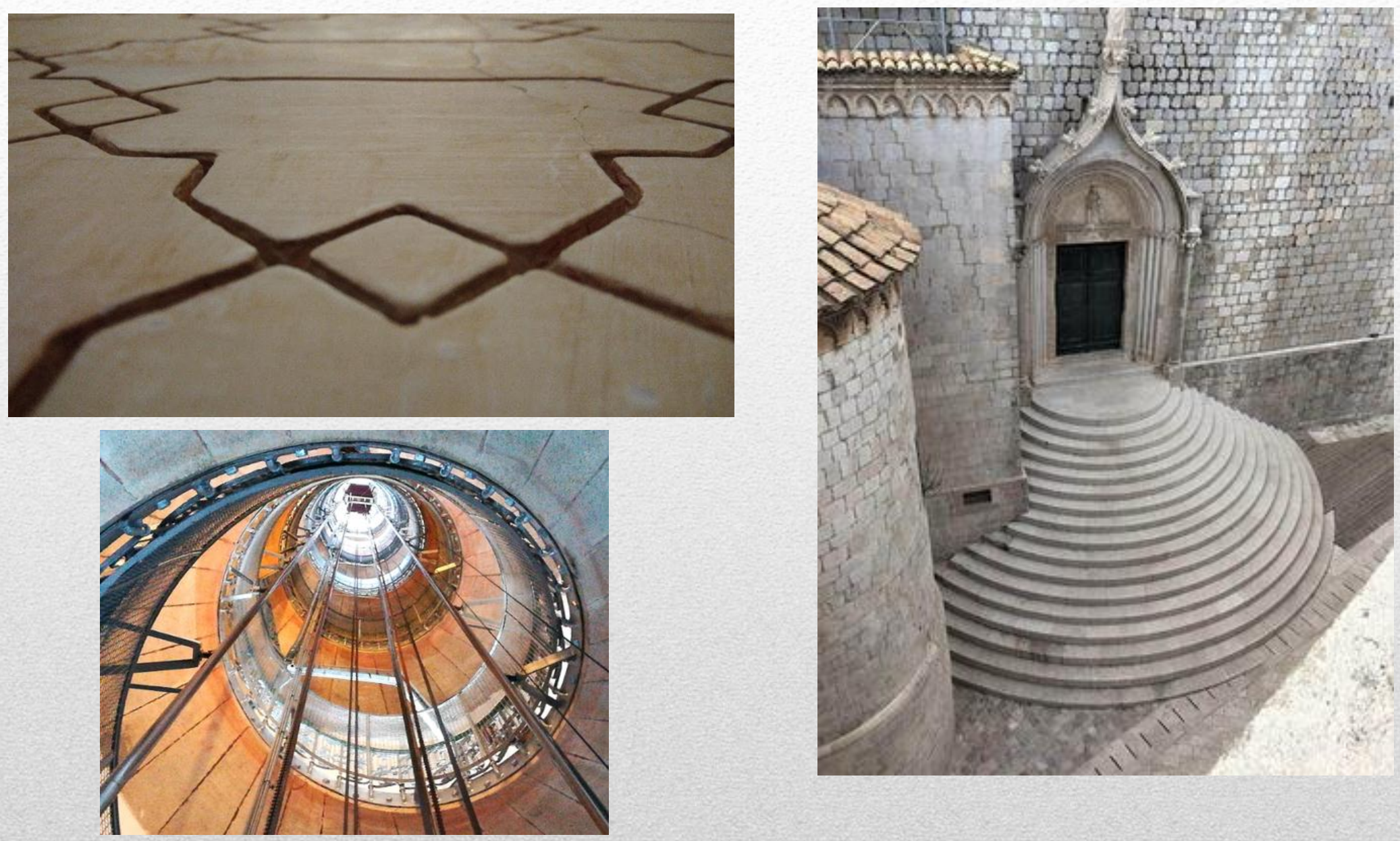

\section{Concursos de fotografía matemática}




$$
\text { 漓: }
$$
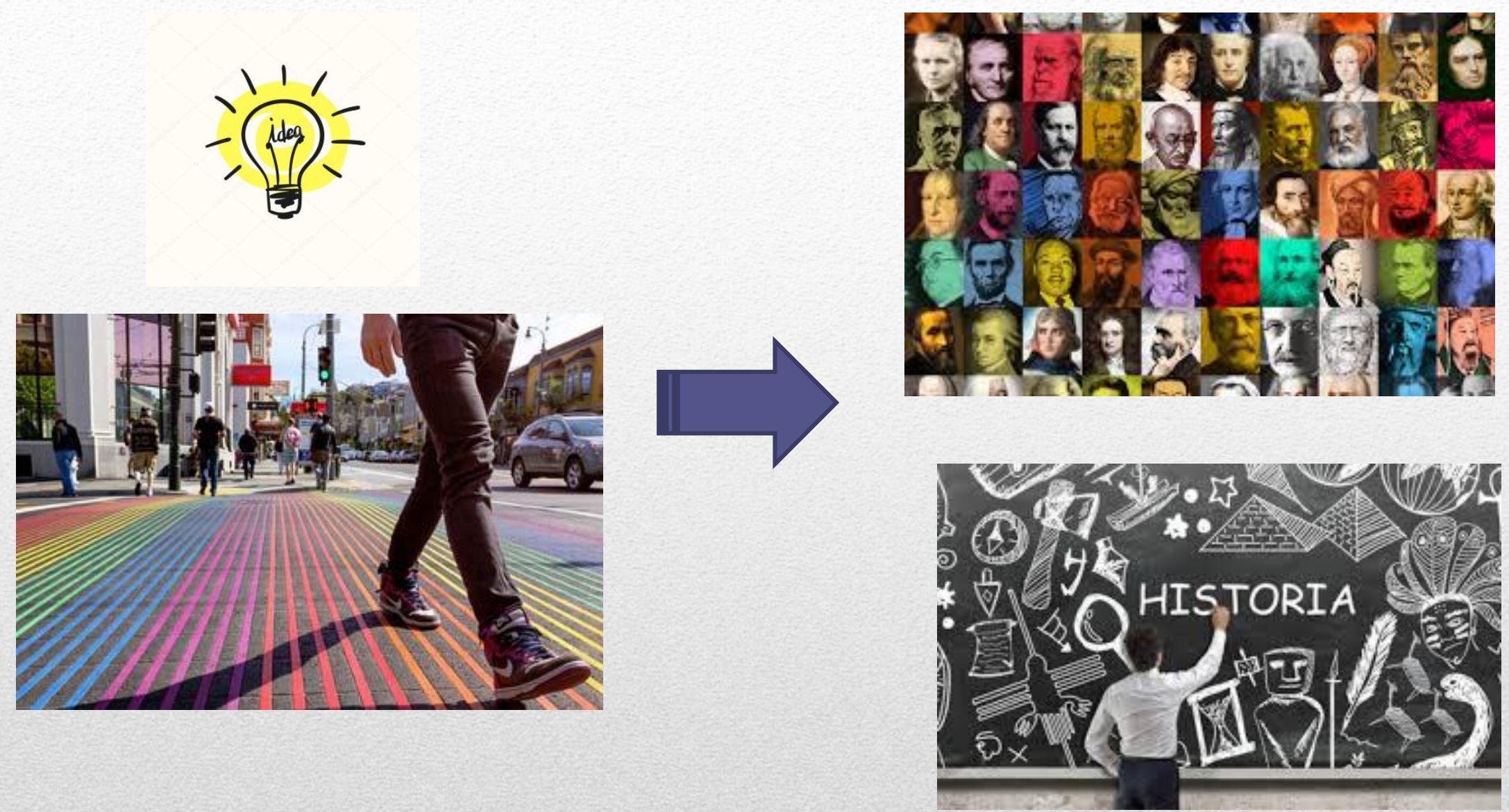

https://erasmusplusmaths.wixsite.com/erasmusplusmaths/challenges

2. Retos matemáticos. 

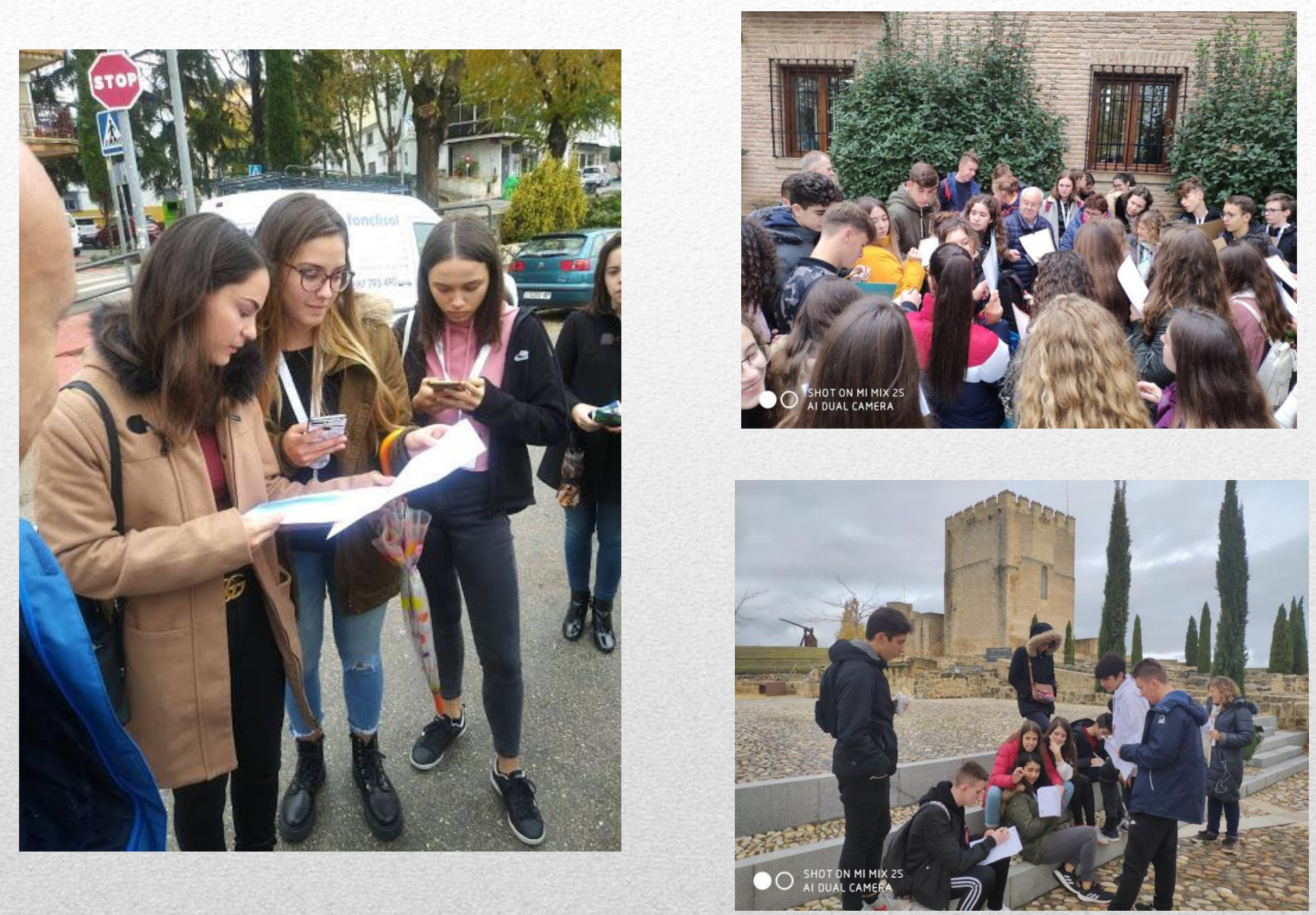

Movilidad 1. Spain 
In the Town Hall' Square, the local sculptor famous statue Martinez Montanez is found.

This great painter produced a great quantity of works, a good number of them still appear in the Easter in so important cities such as Seville. We must remember that Martinez Montañez made several images from Christ in the cross, well, we talk about crosses...if the longitude of the segment marked over the drawing is $\sqrt{2} \cdot \pi$ which is the area of the cross? Note: the cross is set up by six identical squares. Likewise, take into account that you must offer the

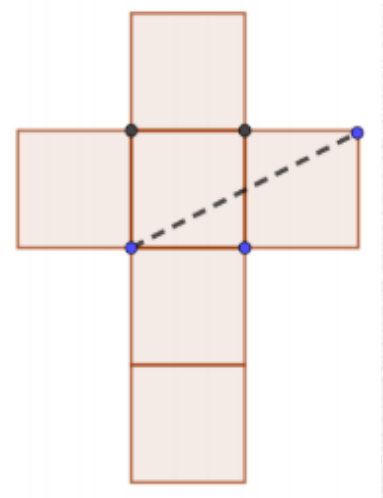
solution based on pi.

The musician' shrine in Paseo de Los Alamos, where we are, is used in certain occasions to carry out particular musical event. Knowing that the shrine's floor has an octagonal shape and that the shading region's area is $3 \mathrm{~m} 2$, which is the octagon's area?
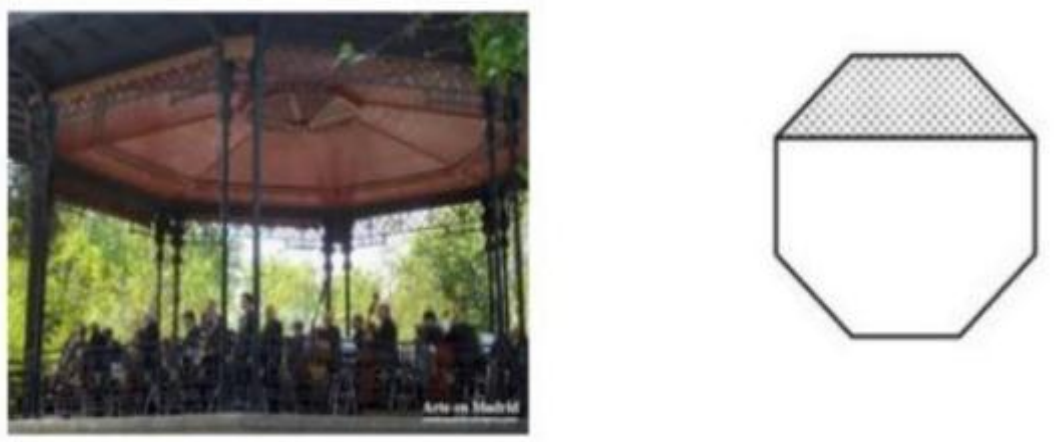

\section{Movilidad 1.Spain}




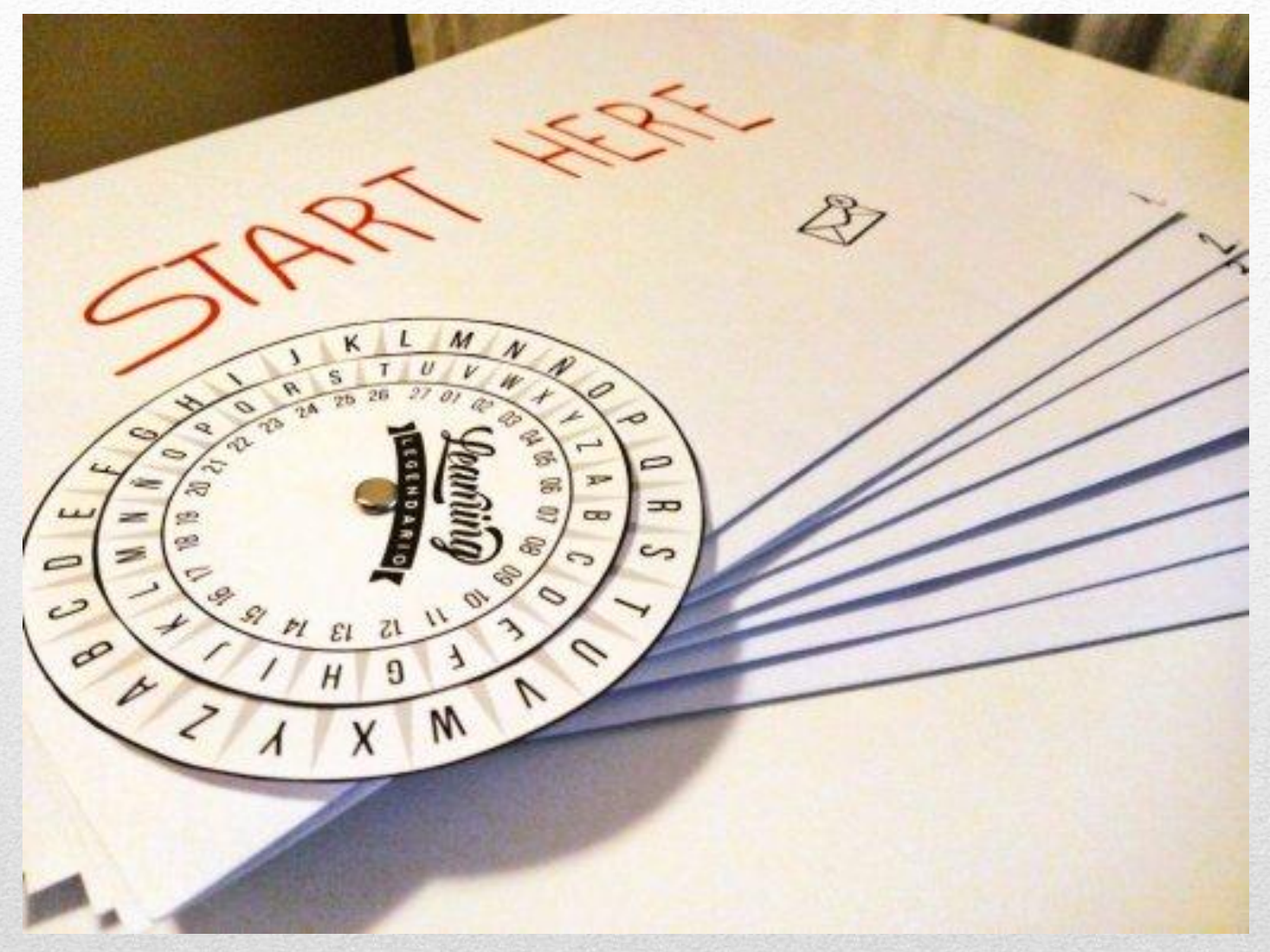

https://twitter.com/EuroMaths/status/1065684189763252224?s=03 Mobility 1. Spain 

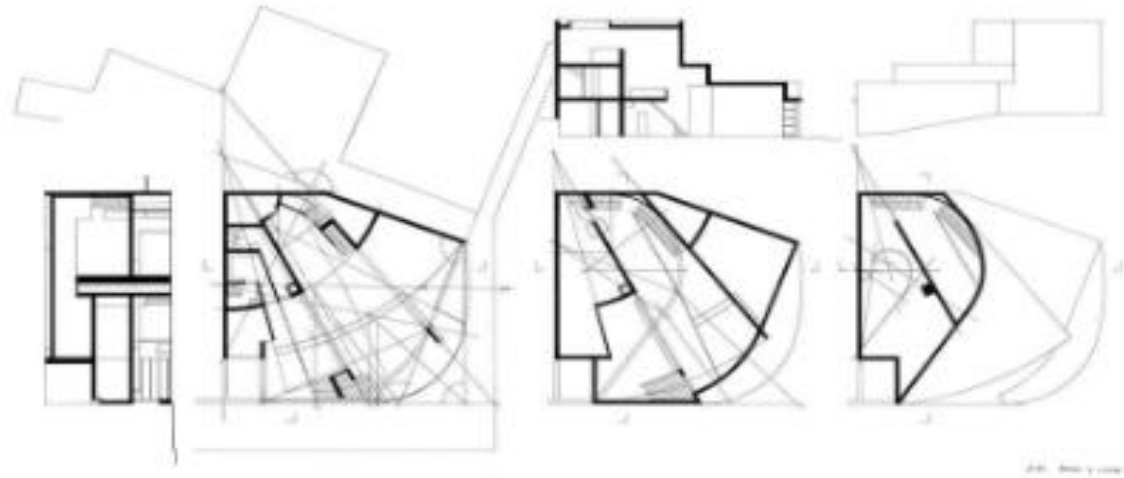

PICK'S THEOREM is one of those theorems in mathematics which seems too simple to be true. Take any polygon and lay it on a lattice. (A lattice is a grid of points where every point has whole number (integer) coordinates.) According to Pick's Theorem all you need to do to find the area of a polygon is to count the points on the interior and on the boundary of the shape.

Pick's Theorem then states that:

$$
\text { Arca }=i+\frac{b}{2}-1
$$

( $i$ stands for the number of points in the interior of the shape, $b$ stands for the number of points on the boundary of the shape.)

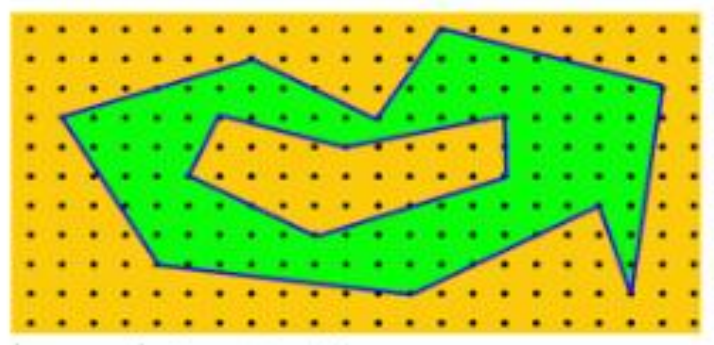

If one of the floors of the building has a polygonal shape, determine its area.

\section{Movilidad 2.Portugal.}


Our last stop will be at Ribeira one of Porto's iconic places.

The Cube in Ribeira is made of bronze, it is fixed upon one of its vertices and is integrated into the reconstruction of an old fountain that was found in the area. To place it where it stands today, a vertex was cut, as shown in the picture.

Which of the following models corresponds to the truncated cube?
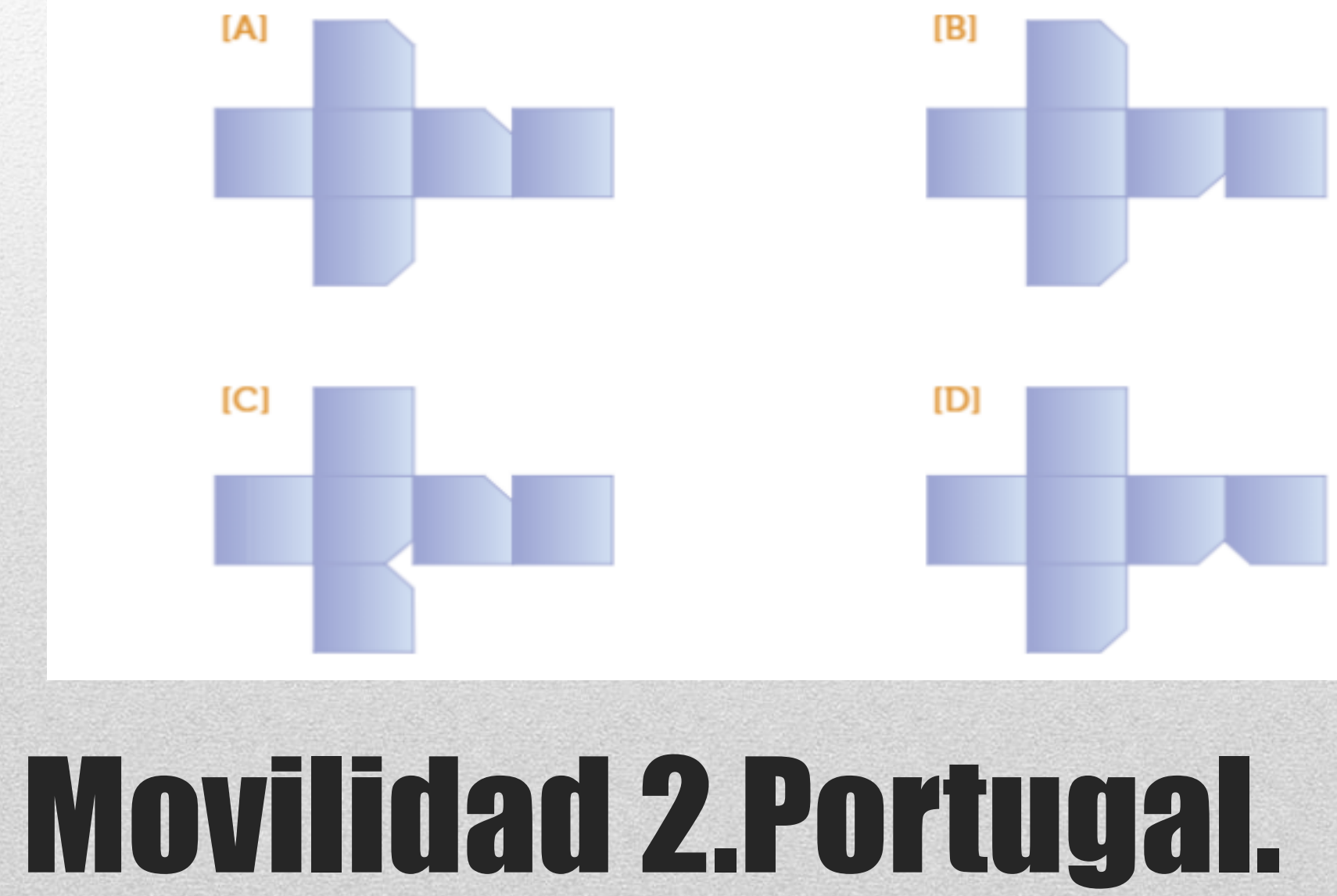


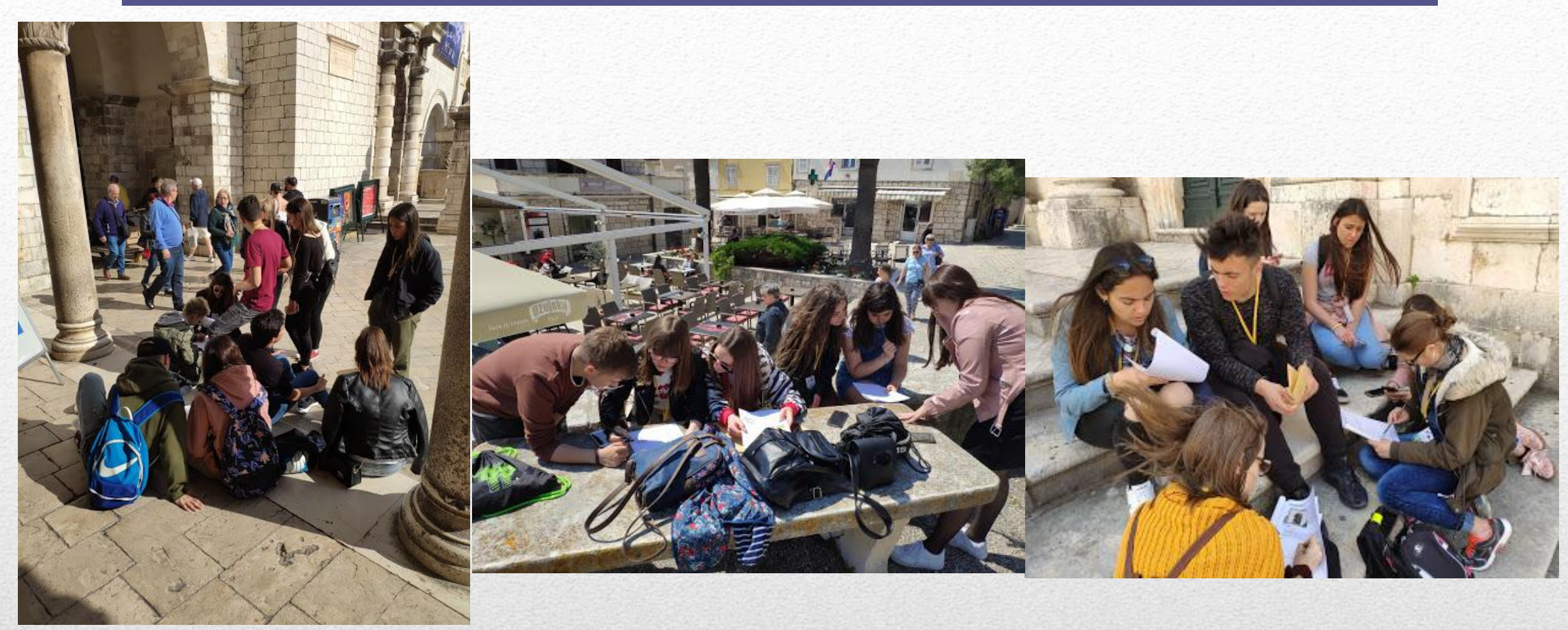

https://twitter.com/EuroMaths/status/1125450295071391746?s=03

https://twitter.com/EuroMaths/status/1125449965181054978?s=03 Movilidad 3. Groacia. 


\section{CHALLENGE 6.}

1. Set the parabola equation

2. Can the equipment $3 \mathrm{~m}$ wide and $2.5 \mathrm{~m}$ high be brought into the atrium of the rector's palace?

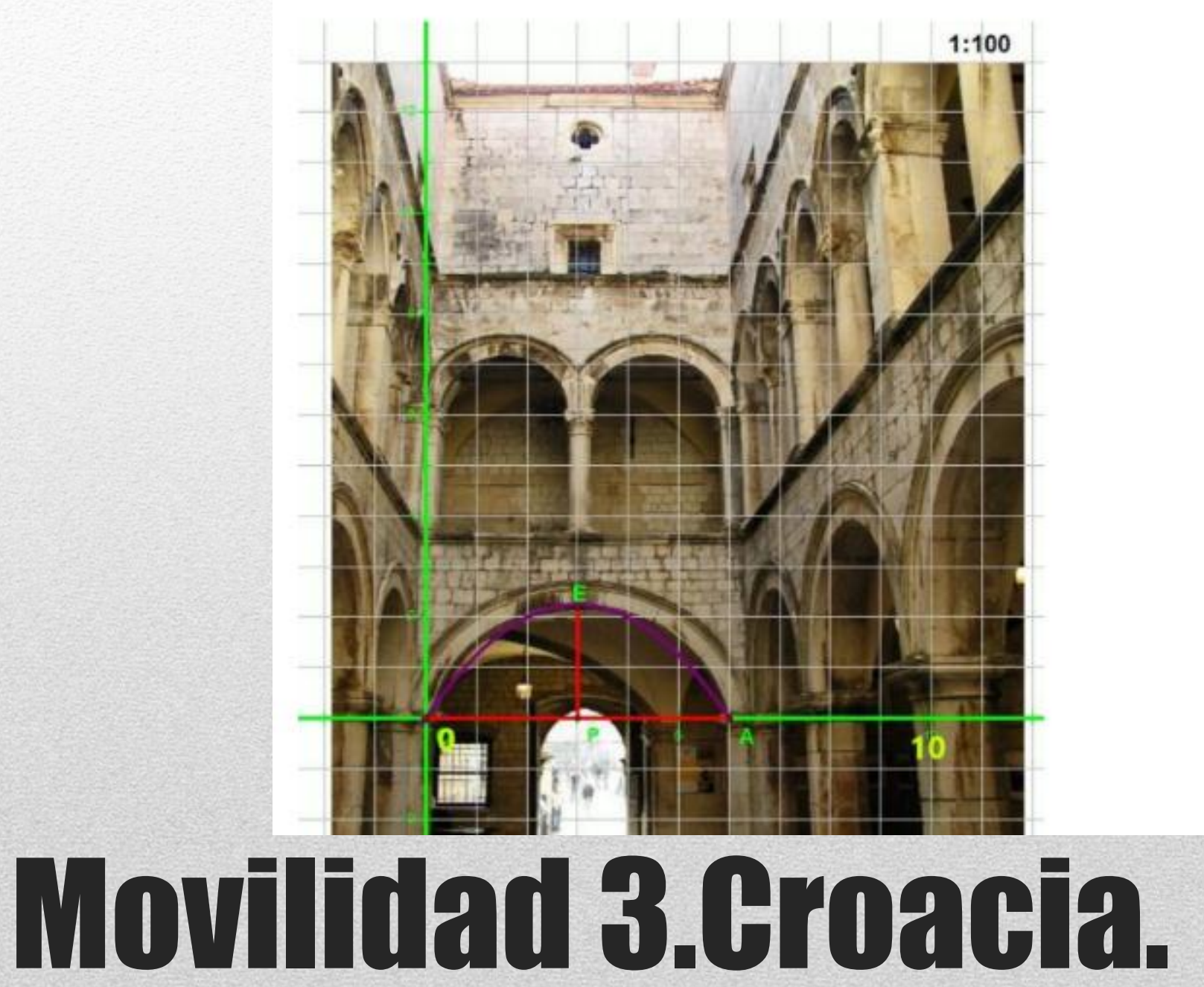




\section{Neretva specialties}

While enjoying the landscape of the region, tourists can sample the delights of many specialties; including fish and frogs, as well as the fruits and vegetables which grow here in abundance. Cruising in an ancient Neretva boat through the meandering rivulets and channels of the Neretva valley, one can enjoy the clear waters of the Norin, a tributary of the River Neretva.

Stories are told of sunken towns, of ancient heroes and famous travelers who wrote down their fascination with the region, thereby recording their impressions of the Neretva valley for eternity.
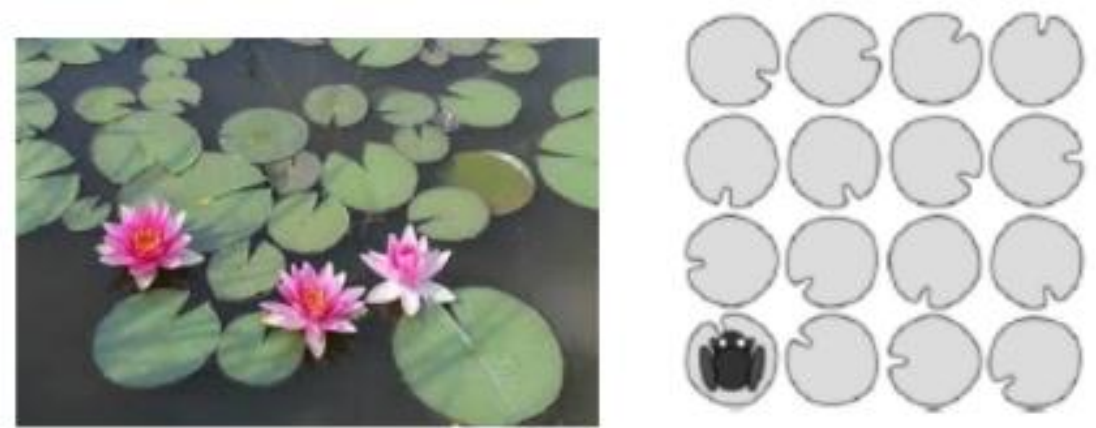

On the River Norin, there are 16 water lilies arranged in a $4 \times 4$ form, as shown in the picture above. On one of the lilies, a frog is sitting in the bottom left corner. It can move horizontally and vertically from lily to lily, so that it always skips at least one leaf and never lands on the same leaf twice. Note that this rule does not apply to the starting lily. What is the largest number of jumps that the frog can do?

\section{Movilidad 3.Groacia.}


During the 2nd century B.C., Romans became very interested in Narona. In 156 B.C., Roman soldiers lead by Gaius Marcia Figulus waged war against the Daors. They probably used Narona as their main base.

After the Octavian's war in 33 B.C., there was a significant influx of population in Narona. For that reason, Narona became a colony during the Caesar's or Augustus' rule. During the Roman Empire, buildings of public importance were built in the eity, such as the forum, temples, thermae, the theater etc.

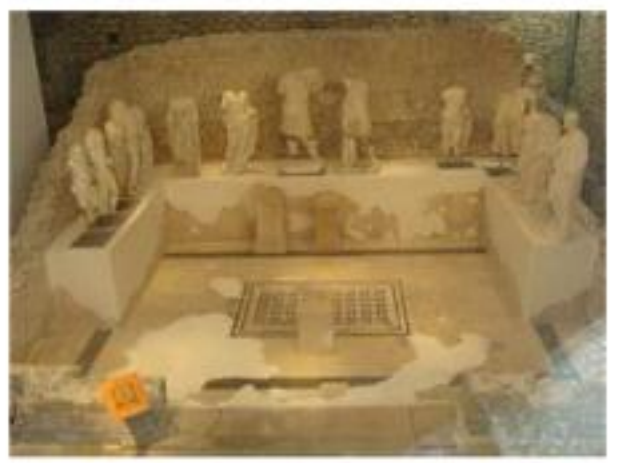

In the bottom picture you can see a pattern of a Roman Temple paving.
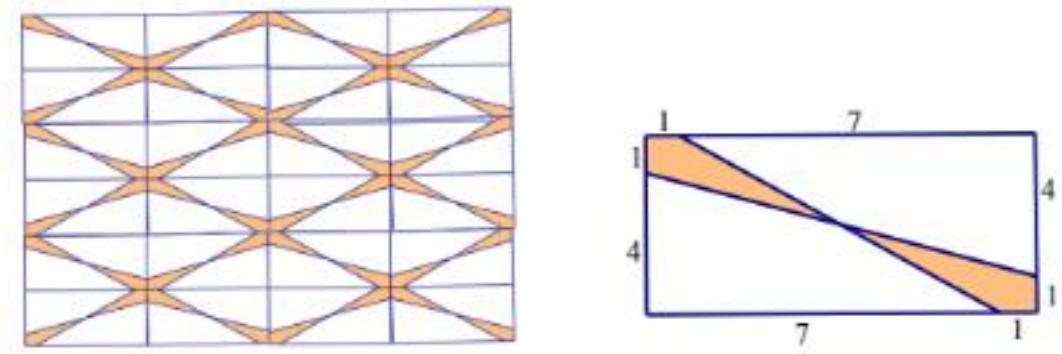

Calculate the size of the shaded region of given rectangular tiles?

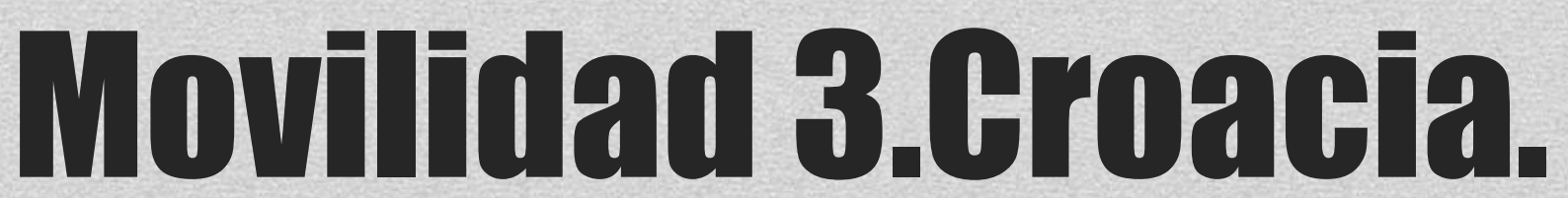




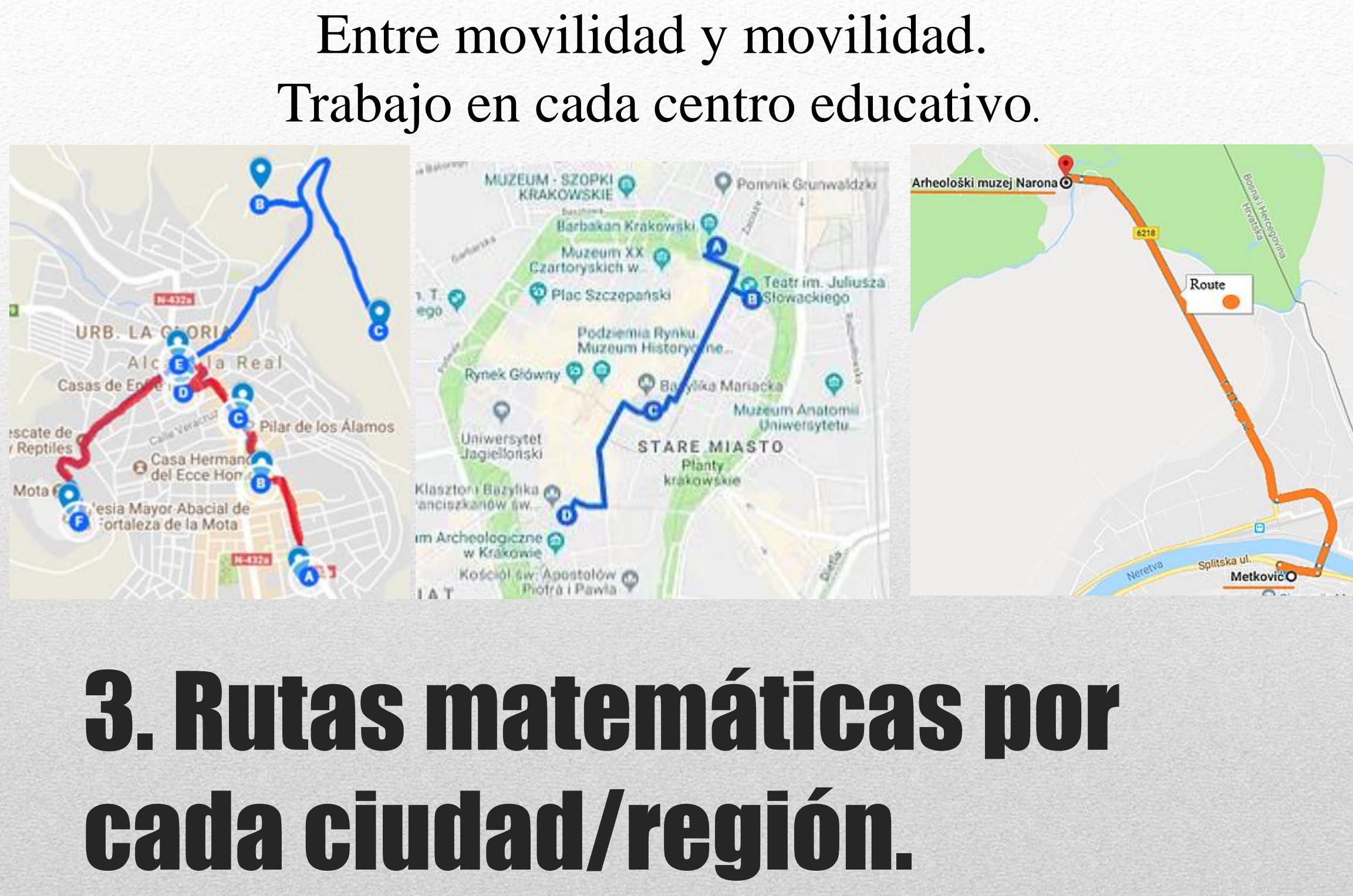



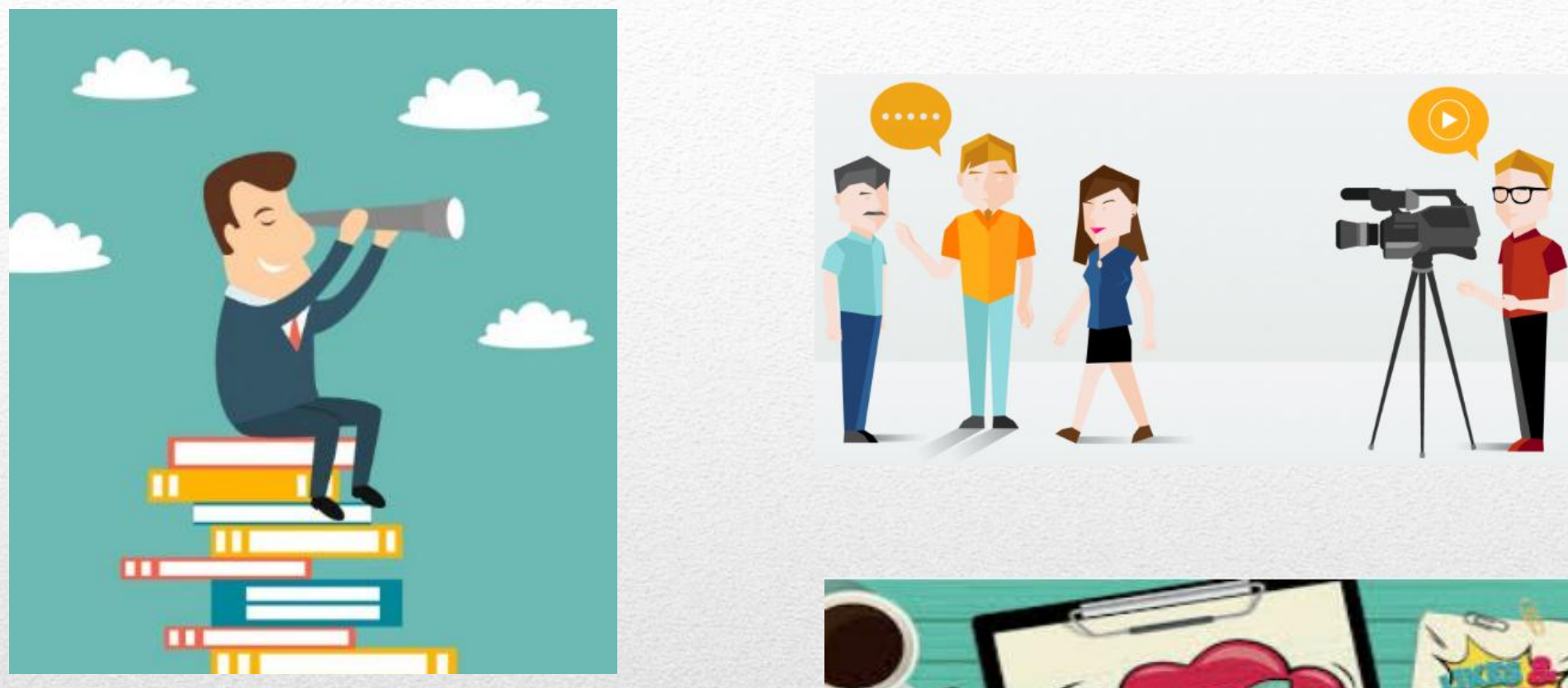

SE BUSCA, SE GRABA, SE ESCRIBE EN EL BLOG

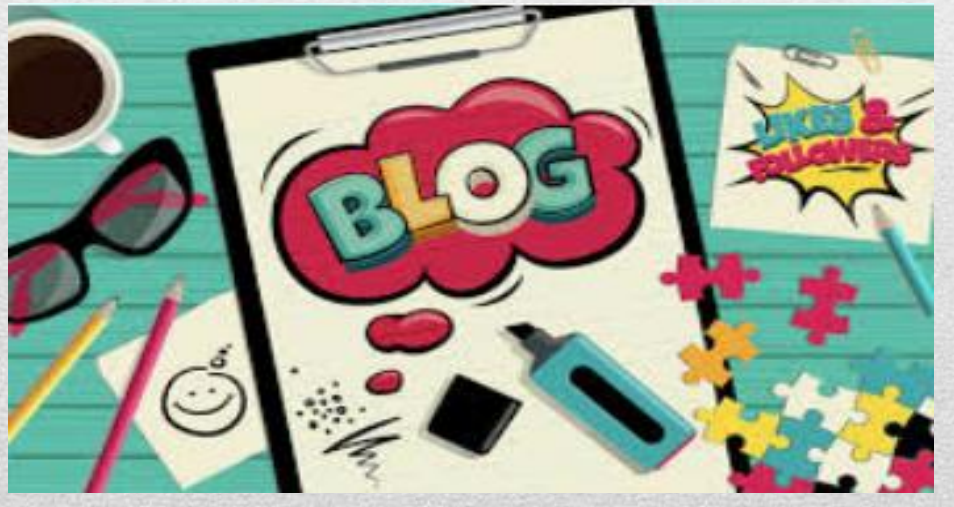

Qué se hace. Se preparan las rutas matemáticas poco a poco. 
https://erasmusplusmaths.wixsite.com/erasmusplusmaths/post/friezes-inalcal\%C3\% A1-la-real-1

https://erasmusplusmaths.wixsite.com/erasmusplusmaths/post/the-trains-exercise

https://erasmusplusmaths.wixsite.com/erasmusplusmaths/post/sailing-club

https://erasmusplusmaths.wixsite.com/erasmusplusmaths/post/the-walls-of-ston

https://erasmusplusmaths.wixsite.com/erasmusplusmaths/post/the-portuguese-tiles

https://erasmusplusmaths.wixsite.com/erasmusplusmaths/post/cable-car-ofsr\%C4\%91-3

https://erasmusplusmaths.wixsite.com/erasmusplusmaths/post/diamonds-of-ferrara

https://erasmusplusmaths. wixsite.com/erasmusplusmaths/post/let-s-do-maths-1

\section{Qué se hace [Ejemplos de entradas al blog hechas por el alumnado].}




\section{Cuatro}

QUÉ IMPLICA ESTO EN NUESTRO GENTRO 


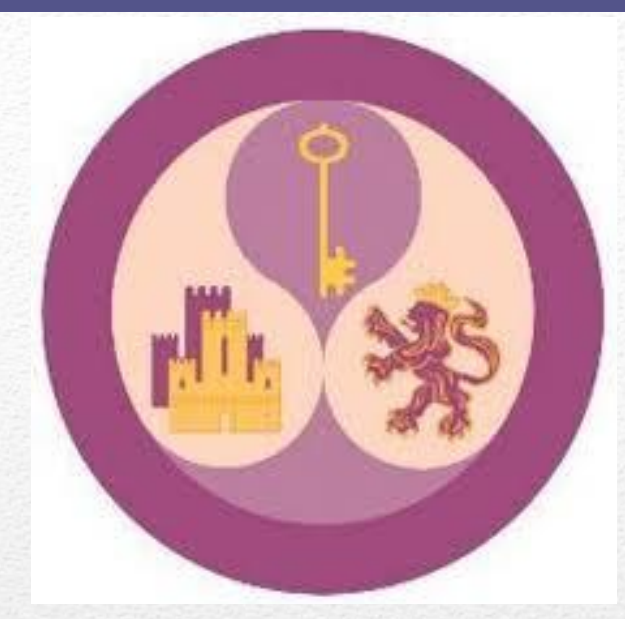

- Proyecto de investigación para $4^{\circ}$ ESO $\underline{\text { VER }}$

- Proyecto de investigación para $1^{\circ}$ de Bachillerato VER

\section{Proyectos trabajados en clase de mates relacionados con el Erasmus+.}




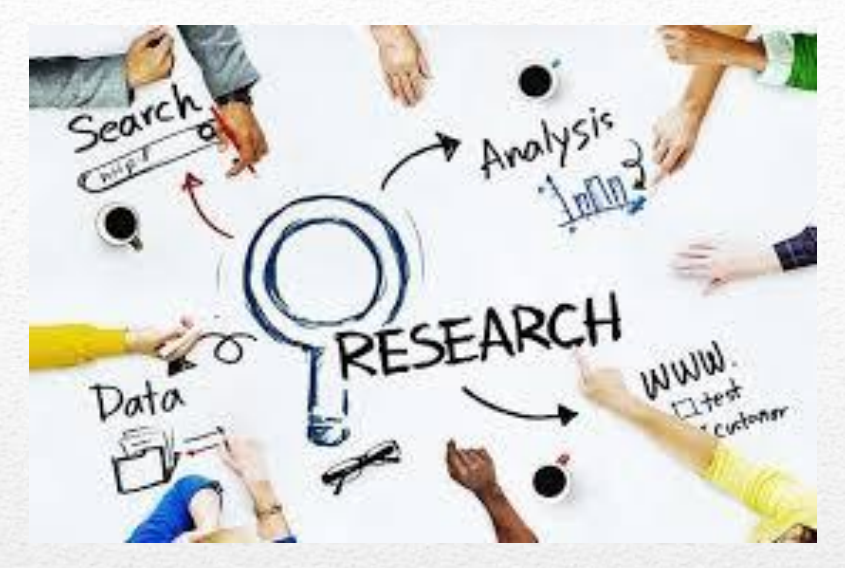

- Proyecto de investigación para $4^{\circ} \mathrm{ESO} \underline{\mathrm{VER}}$

- Proyecto de investigación para $1^{\circ}$ de Bachillerato VER 


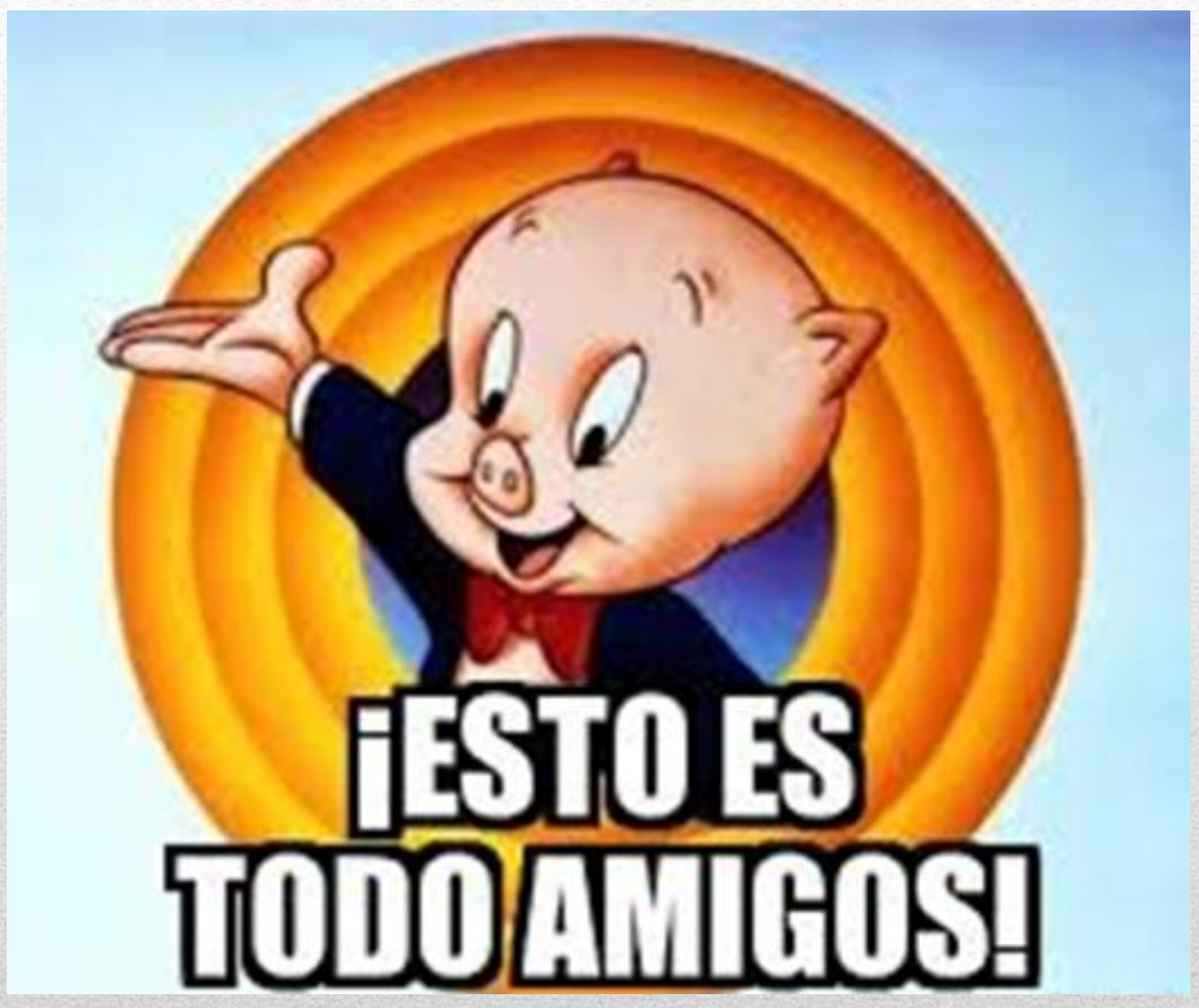




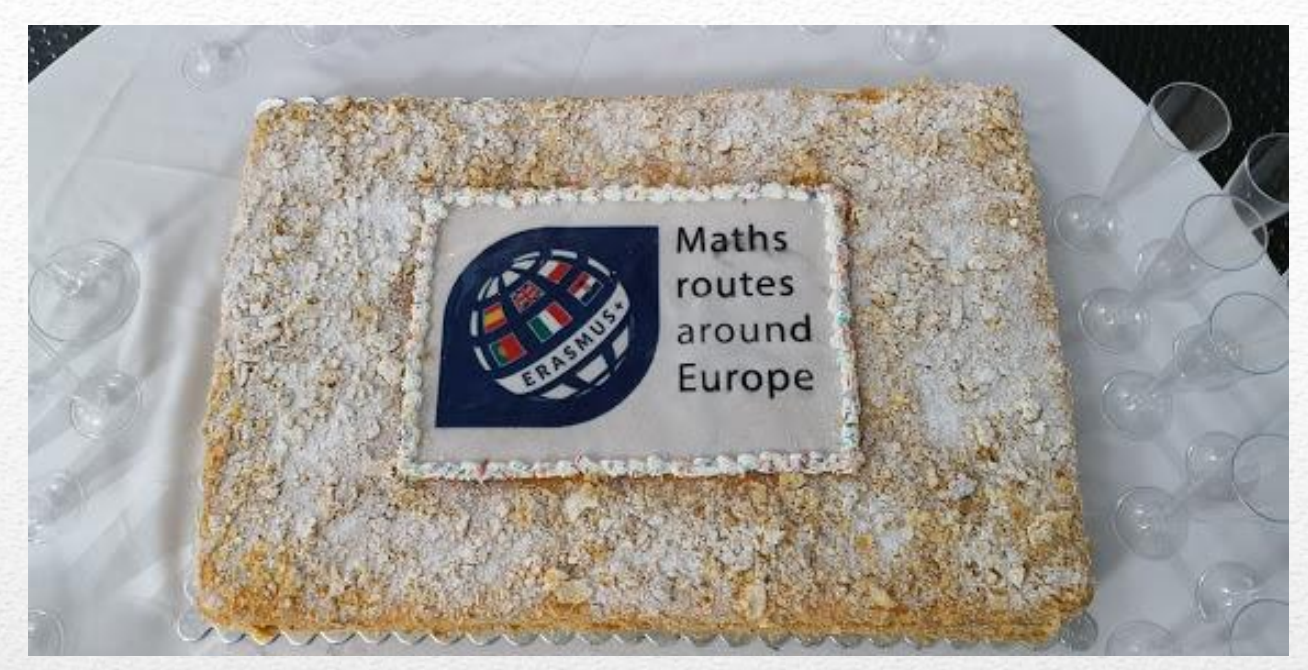

https://erasmusplusmaths.wixsite.com/erasmusplusmaths

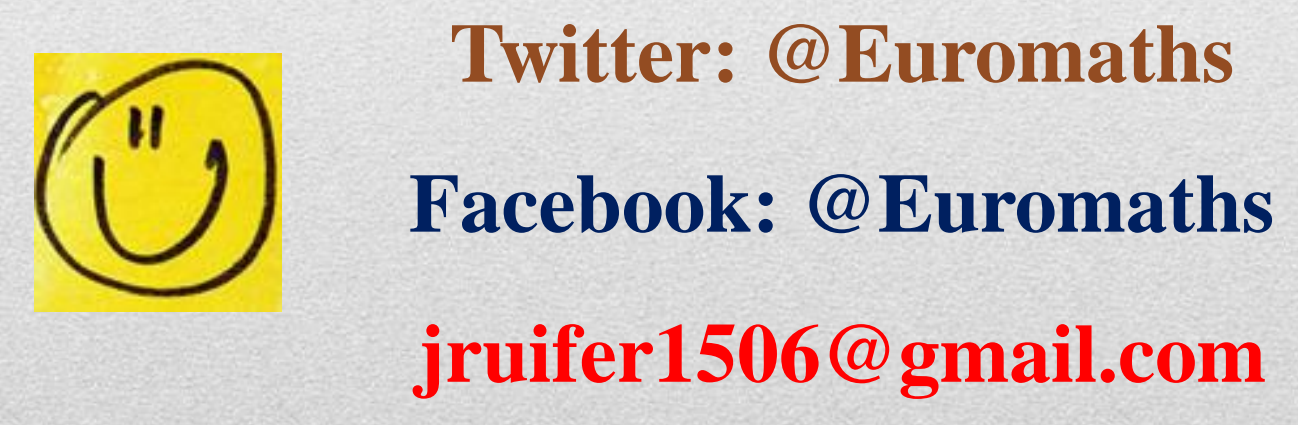

\section{Aracias por vuestra atención.}

